\title{
Powdery Mildew of Japanese White Birch Caused by Erysiphe ornata var. ornata in Korea
}

\author{
Sang-Hyun Lee ${ }^{1}$, Kyung-Hee Kim ${ }^{1}$, Mi-Jeong Park ${ }^{2}$ and Hyeon-Dong Shin ${ }^{2 *}$ \\ ${ }^{\prime}$ Division of Forest Diseases and Insect Pests, Korea Forest Research Institute, Seoul 130-712, Korea \\ ${ }^{2}$ Division of Environmental Science and Ecological Engineering, Korea University, Seoul 136-701, Korea
}

(Received on April 6, 2010; Accepted on May 14, 2010)

Betula platyphylla var. japonica (Miq.) Hara, or Japanese white birch, is a tree which is widely distributed in East Asia. In July 2009, some young trees showing typical symptoms of powdery mildew disease on both sides of their leaves were first found at Hongneung Arboretum, Korea Forest Research Institute, Seoul, Korea.

White superficial colonies developed amphigenously on affected leaves (Fig. 1A \& B). Appressoria were multi-lobed to moderately lobed (Fig. 1C). Conidiophores were 60-100 $\times 10-14 \mu \mathrm{m}$, and composed of slightly curved to flexuous basal cells and one to three cylindrical cells (Fig. 1D \& E). Conidia, devoid of fibrosin bodies, were oblong to cylindrical, with wrinkling surface, $32-42 \times 12-16$ $\mu \mathrm{m}$, and producing perihilar germ tubes (Fig. $1 \mathrm{~F} \& \mathrm{G}$ ). Chasmothecia were spherical, 70-95 $\mu \mathrm{m}$ in diameter. Appendages were 8-18 per chasmothecium, 0.8-1.3 times as long as the chasmothecial diameter, nearly straight, 3.5-9 $\mu \mathrm{m}$ wide, thick-walled at the base, but thinner upwards, aseptate or occasionally uniseptate at the base, apex 3-5 times branched, tips of the ultimate branchlets recurved. Asci were 3-6 per chasmothecium, 50-67 $\times 35-43 \mu \mathrm{m}, 5-8$-spored. Ascospores were oval, 22-27×11-14 $\mu \mathrm{m}$ (Fig. 1H \& I). Morphological characteristics of the material are in accordance with the previous records of Erysiphe ornata var. ornata (U. Braun) U. Braun \& S. Takam. (formerly Microsphaera ornata var. ornata U. Braun). This variety differs from var. europaea having fewer (ca 410) and shorter appendages (Braun, 1987).

The complete ITS region of rDNA from KUS-F24679 was amplified with primers ITS5 and P3 and sequenced, and the

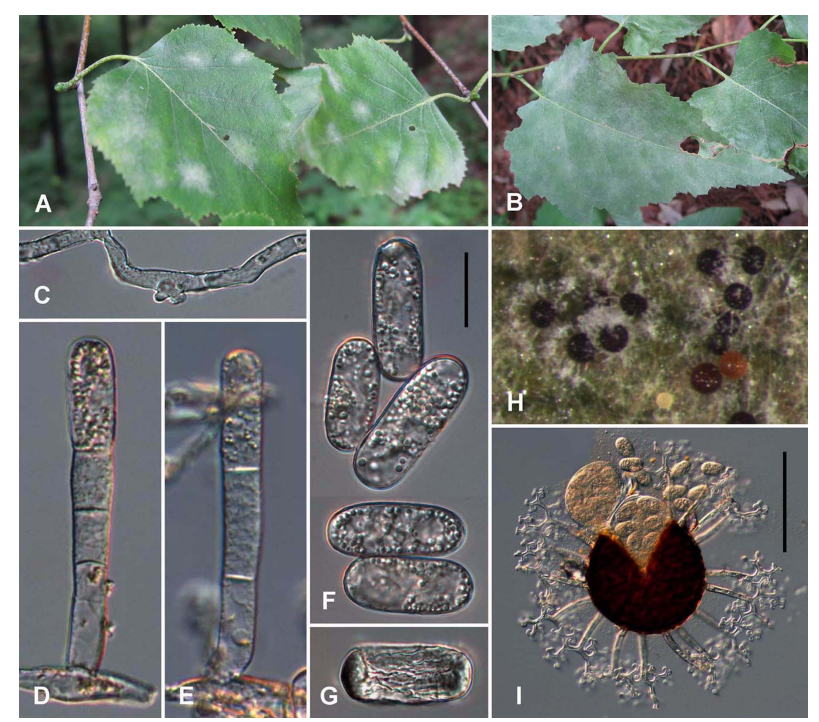

Fig. 1. Powdery mildew infections of B. platyphylla var. japonica caused by $E$. ornata var. ornata. Early, circular symptoms (A) and later, effused mycelial layers (B) on upper leaf surface. Appressorium (C), conidiophores ( $D \& E$ ), conidia $(F \& G)$, chasmothecia formed on lower leaf surface $(\mathrm{H})$ and a chasmothecium producing 6-8-spored asci (I). Bar= $20 \mu \mathrm{m}$ for $\mathrm{C}-\mathrm{G}$ and $100 \mu \mathrm{m}$ for I. resulting sequence was deposited in GenBank (HM057441). A BLAST search showed that there was no comparable sequence of $E$. ornata and thus this was the first ITS sequence for the species submitted in GenBank. To infer the relationship between $E$. ornata var. ornata and other Erysiphe species, a phylogenetic tree (Fig. 2) was constructed using MEGA4, version 4.0 with neighbor-joining method and Tajima-Nei model.

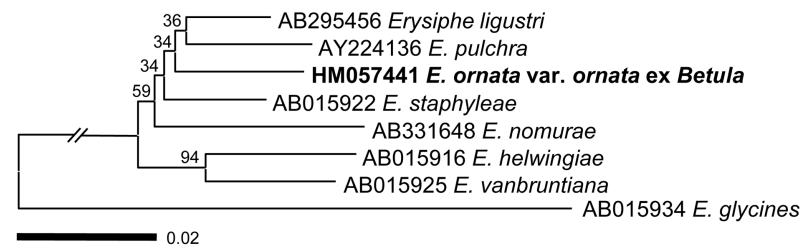

Fig. 2. Phylogenetic relationship between Erysiphe ornata var. ornata on Betula platyphylla var. japonica and other Erysiphe species, inferred by neighbor-joining method using the ITS rDNA region. Numbers above the branches represent the bootstrap values. Bar=Number of nucleotide substitutions per site.

According to Braun (1987), E. ornata var. ornata on Betula spp. is widespread in North America, known in Asia (Central Asia, Siberia, Far East of Russia) and very rare in Eastern Europe. In China, Microsphaera betulae Magnus (actually E. ornata var. ornata in the current concept) on Betula spp. was recorded from Xinjiang by Zhao (1979) and from Inner Mongolia by Liu (1997). Interestingly, beginning in the 1990s there have been new records of E. ornata var. ornata on Betula spp. from Estonia, Poland, Serbia, Switzerland and Ukraine (see Farr and Rossman, n.d.). This suggests that E. ornata var. ornata, the North American powdery mildew fungus, has been spreading to Europe and Asia in recent years. This is the first confirmed report of E. ornata var. ornata in East Asia and the first record of B. platyphylla var. japonica as its host plant.

\section{Acknowledgements}

We are very grateful for helpful discussions with Drs. U. Braun (Germany), S. Takamatsu (Japan) and T. Z. Liu (China). We also thank Dr. M. S. Choi for identifying the host plant.

\section{References}

Braun, U. 1987. A Monograph of the Erysiphales (Powdery Mildews). Beih. Nova Hedwigia 89:1-700.

Farr, D. F. and Rossman, A. Y. n.d. Fungal Databases, Systematic Mycology \& Microbiology Laboratory, ARS, USDA. Retrieved March 30, 2010, from http://nt.ars-grin.gov/fungaldatabases/

Liu, T. Z. 1997. Studies on Taxonomy and Flora of Powdery Mildews (Erysiphaceae) in Inner Mongolia, China. Ph.D. Dissertation, Inner Mongolia University, Hohhot, China.

Zhao, Z. Y. 1979. Flora of the Erysiphaceae in Xinjiang. Xinjiang People's Press, Xinjiang, China. 151 pp. (in Chinese)

*Corresponding author (hdshin@korea.ac.kr) 